ISLLAC

Journal of Intensive Studies on Language, Literature, Art, and Culture

Vol. 1 No. 1 September 2017

\title{
INCREASING THE ROLE OF LEARNING PORTUGUESE LANGUAGE FOR ESTABLISHING THE NATIONS CHARACTER OF TIMOR LESTE
}

\author{
Dr. Agostinho dos Santos Gonçalves, S.E, M.M \\ Email: santosagostinho@yahoo.com \\ Instituto Superior Cristal Dili Timor Leste
}

\begin{abstract}
The study outlined in this article aimed to describe the increasing the role of learning Portuguese for establishing the national character of Timor Leste. Portuguese language learning in Timor Leste needs to be developed seriously. The learning condition of the language still faces many problems, especially related to the material and the learning process. Therefore, the preparation of teaching materials that are truly functional and make it easier for students to learn the language needs to be developed. This needs to be done to make quality learning outcomes. Through quality Portuguese language learning, students will be able to gain understanding and appreciation of the language culture. Cultural insights will have an impact on the building of student character that is compatible with the culture of the nation of Timor Leste.
\end{abstract}

Keywords: the role of learning, Portuguese language, nations character

\section{INTRODUCTION}

Language conditions in Timor Leste are complex. In addition to Portuguese as a national language that must be developed, in Timor Leste, there are several languages that have great influence for the people of Timor Leste. The languages in question are English, Bahasa Indonesia, and a number of regional languages spoken in Bekais, Bunak, Dawan, Fataluku, Galoli, Habun, Idalaka, Kawaimina, Kemak, Lovaia, Makalero, Makasai, Mambai, Tokodede, dan Wetarese. In the Constitution of Timor Leste, it is mentioned that English and Indonesian are used as working languages. In daily practice, many people use Tetum as a social language. Meanwhile, the Indonesian language is widely used for writing learning tasks. In learning in high school, still found Indonesian for a final examination. In general, students and 
ISLLAC

Journal of Intensive Studies on Language, Literature, Art, and Culture

Vol. 1 No. 1 September 2017

lecturers prefer and use the Indonesian language as the language of instruction and writing a scientific essay.

The above fact becomes very ironic if it is linked to the policy of the Government of Timor Leste. In the policy, it is suggested that in every formal meeting it is necessary to use Portuguese. If the meeting is attended by other nations who do not know the language, Indonesian or English will be used to explain the purpose of the conversation delivered in the Portuguese language.

The emergence of Portuguese language learning problems in Timor Leste can be traced from the historical facts of the State of Timor Leste. Prior to becoming a sovereign independent State, Timor Leste was part of the State of Indonesia, the 27th province under the name of Timor Leste. Under the New Order government, Portuguese should not be used as a language of instruction or language as a social language in Timor Leste. However, the current Portuguese language in Timor Leste is widely taught and promoted with assistance from Brazil and Portugal. However, the reality is still a lot of obstacles in the development of the Portuguese language because there is still a reluctance of some among the educated youth in Timor Leste.

The Portuguese language problem in Timor-Leste can be observed from the facts that occur in language usage. Many Timorese still do not speak Portuguese fluently. The validity of this report is questioned by members of the National Institute of Linguistics of Timor Leste who maintain the opinion that Portuguese is spoken by $25 \%$ of the population of Timor. Along with other local languages, Tetum is the most commonly used language to communicate, while Indonesian is still widely used in media and schools from high school to college.

Based on the above description, it can be argued that the existence of Portuguese in education in Timor Leste still faces many problems. This is due to the lack of educators in the mastery of Portuguese language and the inadequacy of learning tools that are able to support the fluency of learning the Portuguese language. In the meantime, Portuguese teachers are mostly non-graduate Portuguese education programs. Likewise, learning support facilities have not been sufficient to accelerate the mastery of Portuguese. 
ISLLAC

Journal of Intensive Studies on Language, Literature, Art, and Culture

Vol. 1 No. 1 September 2017

The above description shows that Portuguese language learning in Timor Leste still requires adequate resource support for the quality of learning to achieve the expected target. In relation to efforts to improve the quality of this learning, Sudjana (2000: 35) suggests that quality learning can be seen from two things, namely the process and product learning. A learning process is said to be of quality if the learning process (PBM) can take place effectively and learners experience a meaningful learning process. Learning products are called qualified when learners show a high level of mastery of learning tasks in accordance with the goals and objectives of education.

Portuguese as a national language needs to be socialized for all nations in Timor Leste. One of the most effective Portuguese language parlors is through the learning process at school. In order to correct the pronunciation of the Portuguese through the learning process, teachers need to develop more innovative learning practices so as to improve students' learning motivation and student learning styles that support the achievement of maximal learning outcomes.

Based on observations in several public high schools and senior high schools in Dili, it is illustrated that Portuguese language learning is conducted conventionally. Learning activities that provide opportunities for students to practice using language for the benefit of communication are lacking. Students are only required to read a package book containing Portuguese subtitles, furthermore, the student answers the content question. Thus, the activity of students in learning less passionate. Teachers in teaching Portuguese also use the Tetum language of instruction, both in explaining and giving instructions to students.From the results of interviews with teachers and questionnaires submitted by students, obtained information that students are less challenged to use the Portuguese language because the teaching materials used have not given opportunities to students to practice communication. In addition, the available materials contain topics that are less suited to students' interests and needs for daily communication. Students study topics outside of their world so that the material becomes less meaningful for students. Finally, the mastery and learning experience that students gain is verbalize. 
ISLLAC

Journal of Intensive Studies on Language, Literature, Art, and Culture

Vol. 1 No. 1 September 2017

The Portuguese language will be mastered by the students easily and smoothly if the instructional material of Portuguese learning is based on the learning needs of the students. These needs include the need to communicate in classroom learning practices or communication needs outside the classroom. In relation to that statement, in the practice of learning, teachers need to have Portuguese teaching materials that match the needs of student communication. Thus, the language he learns can be practiced directly in everyday communication both at school and outside of school.

\section{TIMOR LESTE COMMUNITY}

The Democratic Republic of Timor Leste (RDTL) is a country to the north of Australia and the eastern part of the island of Timor. The territory of this country also includes the island of Goat or Atauro, Jaco, and the Oecussi-Ambeno enclave in West Timor. Timor Leste was once one of the provinces in Indonesia, namely the 27th province. Timor Leste was officially independent on 20 May 2002. When it became a member of the United Nations, they decided to use the Portuguese name "Timor Leste" as the country's official name.

The Head of State of the Republic of Timor Leste is a president, directly elected for a term of 5 years. Although its function is merely ceremonial, the president of Timor Leste has a veto of the law. The Prime Minister is elected from multi-party elections and appointed/appointed from the majority party of a majority coalition. As head of government, the Prime Minister heads the Council of Ministers or Cabinet in the Government Cabinet. Timor Leste's parliament consists of only one room and is called Parlamento Nacional. Members are elected for five-year terms. The number of seats in parliament is between 52 and 65 but is currently 65 . The Constitution of Timor-Leste is based on the Portuguese Constitution. Timor Leste is administratively divided into 13 districts: Aileu, Ainaro, Baucau, Bobonaro, Cova-Lima (Suai), Dili, Ermera, Lautem (Lospalos), Liquica, Manatuto, Manufahi (Same), Oecussi-Ambeno (Pante Makassar) Viqueque (Cabira-Oan). The names that 
ISLLAC

Journal of Intensive Studies on Language, Literature, Art, and Culture

Vol. 1 No. 1 September 2017

are between brackets are the alternative spellings that are often used during the integration period.

The economy of the people of Timor Leste largely includes an economy class with lower middle income by the World Bank and is ranked 158 on the list of HDI. This shows the low level of economic development of the community. There are still many people who are illiterate. Despite its independence, Timor Leste is still heavily dependent on the supply of essential goods from neighboring countries. Politically, Timor-Leste still relies heavily on Portugal. In addition, Timor-Leste adopted the US Dollar currency as a currency that resulted in the purchasing power of the people much lower than when it was still a province of Indonesia.

In 2005 Timor Leste's population was estimated at 1,040,880 inhabitants. The population of Timor Leste is a mixture of Malay and African tribes, a small part of Portuguese descent. The majority of the population is Catholic $(93 \%)$, followed by Protestant (3\%), Islam (1\%), and Buddhist, $1 \%, 0.5 \%$ ), and $2 \%$ confidence. Since the majority of the population is Catholic, there are now three dioceses: Dili Diocese, Baucau Diocese, and Maliana Diocese newly established on 30 January 2010 by Pope Benedict XVI.

\section{PORTUGUESE LANGUAGE CONDITION IN TIMOR LESTE}

Since Timor Leste's independence in 2002, since 1999 under the UN transitional government, Timor-Leste's constitution has two official languages, Tetun and Portuguese. In addition, in the constitution also mentioned that English and Indonesian language work language. In daily practice, the public uses the Portuguese Tetun as the spoken language. Meanwhile, the Indonesian language is widely used for writing. For example, high school students still use Bahasa Indonesia for the final examination. Many students and lecturers prefer to use the Indonesian language as the language of instruction and writing scientific papers. In addition, there are also dozens of regional languages, among them: Bekais, Bunak, Dawan, Fataluku, Galoli, Habun, Idalaka, Kawaimina, Kemak, Lovaia, Makalero, Makasai, Mambai, Tokodede, and Wetarese. 
ISLLAC

Journal of Intensive Studies on Language, Literature, Art, and Culture

Vol. 1 No. 1 September 2017

While still part of the Unitary State of the Republic of Indonesia, the use of Portuguese is prohibited. Currently, Portuguese in Timor Leste is widely taught and promoted with assistance from Brazil and Portugal, despite the reluctance of some educated youth. According to the 2006 UN Development Report, only less than 5\% of Timorese speak Portuguese fluently. Nevertheless, the validity of this report is questioned by members of Timor's national linguistic Institute, who maintains the notion that Portuguese is spoken up to $25 \%$ of the population of Timor. Along with other local languages, Tetum is the most commonly used language to communicate, while Indonesian is still widely used in media and schools from high school to college. Most of the words in Tetum are from Portuguese, but there are also absorbing words from Indonesian, for example, the number notation.

The Portuguese language development process in Timor-Leste still has many problems. The use of Portuguese language is not evenly distributed among the people because it can only be understood and used by educated people. Although already understand the Portuguese language, most people who are literate still use their own local language. This is because as part of the Indonesian government, the use of Portuguese in daily conversations is prohibited, while the use of Tetum and Indonesian languages is encouraged to be disseminated.

In addition to the conditions described above, the people of Timor Leste also come from 300 tribes, with 16 different languages. Of the twelfth language, Tetun is the most widely used local language to date. Most Timorese people can use up to 4 languages in communicating with each other. Such a condition becomes a new problem when the Constitution of the Democratic Republic of Timor Leste has been ratified by article 13 paragraph 1, that Portuguese and Tetum are official languages of the Democratic Republic of Timor Leste.

The Portuguese language that was buried during the reign of Indonesia was present again, while Tetunese (the mother tongue of Timor Leste, although there was a distinct regional language in every region of Timor-Leste) underwent a change during the Portuguese and Indonesian colonialists, Tetun Terik (the native Tetun) in Tetun Prasa (the Tetun language that absorbs vocabulary from Portuguese and 
ISLLAC

Journal of Intensive Studies on Language, Literature, Art, and Culture

Vol. 1 No. 1 September 2017

Bahasa Indonesia) is not properly organized. Tetun was not placed in the educational curriculum during the Soeharto regime. As a result, books in Tetun are rarely found, except the Bible and some of the books and dictates of the church translated in Tetum by pastors. Tetun language that has been entrenched become thin by the invaders, and the linguists need more time to organize the mother tongue.

Changes in government administration that led to the change of language policy in Timor Leste also affected the education system from Kindergarten to University. The language of instruction has changed from Indonesian to Portuguese and Tetun. This makes the teacher and students have difficulty in teaching and learning process. The textbooks should be translated into Portuguese and Tetun, while textbooks imported from CPLP countries (Portuguese Speaking Countries) are difficult for teachers to use because they are mostly from people who are not fluent in Portuguese.

This problem becomes even more complicated when further examined the issue of Timorese public interest in education. Every year many Timorese students choose to study in Indonesia because Indonesian is easier to understand and tuition in Indonesia is cheaper than the Portuguese, Australia and other countries. The problem is whether on their return from Indonesia they have to take the Portuguese course again. This process is happening in Timor Leste. This generation of Indonesians has to deal with a new generation of independence generation, the Timor Lesteese who, having begun to adapt to the 'Portuguese' environment, are more fluent in the language. The schoolroom is one where these two generations meet. This generation of Indonesian tongues acts as a teacher. Therefore, it can be imagined communication difficulties that occur due to the different languages.

\section{LANGUAGE LEARNING}

Learning is defined by educational experts differently according to their respective perspectives on learning processes and outcomes. Slameto (2010: 2) defines learning as a process of doing something that a person does to gain a whole new behavioral change, as a result of his own experience in interaction with his 
ISLLAC

Journal of Intensive Studies on Language, Literature, Art, and Culture

Vol. 1 No. 1 September 2017

environment. Meanwhile, Skinner (in Dimyati 2009: 9) views that learning is a behavior. At the time people learn, the response becomes better and vice versa if not learn the response becomes decreased, whereas according to Gagne (in Dimyati 2009: 10) learning is a set of cognitive processes that change the nature of the stimulation of the limits, through the processing of information, into a new capacity. Learning in this paper means all efforts given by the teacher to be able to master the learning materials that have been received that can create changes in new behavior and learning can be interpreted to try (practice and so forth) in order to gain an intelligence.

Learning is also defined as a process, meaning that in learning will occur the process of seeing, making, observing, solving problems or problems, listening, and practice. In the process of learning the teacher must be able to guide and facilitate students in order to make the learning process. The learning process should be strived effectively to change behavior. A person can be said to learn because of the indication of learning process consciously and produce behavioral changes obtained based on interaction with the environment. The environment in question is resource persons, friends, teachers, real situations and conditions, natural environment, artificial environment that can be used as a source of learning.

Learning can be through direct experience and through indirect observation. Learning through hands-on experience is the students doing themselves or by experiencing their own, experimental examples. However, when students know because reading books or listening to teacher explanation is called learning through indirect experience. Learning is defined as an effort to make students learn (Degeng 1997: 1). Starting from the definition of learning can be interpreted as an activity that provides good learning facilities resulting in the learning process. Provision of learning facilities for students requires a strategy, namely learning strategies. According to Piaget (in Dimyati 2009: 14-15), learning consists of four steps, namely (a) determining topics that can be learned by the children themselves, (2) selecting or developing classroom activities with the topic, (3) teachers to ask questions that support the problem-solving process, and (4) assess the implementation of each 
ISLLAC

Journal of Intensive Studies on Language, Literature, Art, and Culture

Vol. 1 No. 1 September 2017

activity, pay attention to success, and revise it. Based on the description, it can be concluded that language learning is a learning process implemented by teachers and students in assessing the language with the aim of achieving success in the form of learning outcomes and the ability of students in processing and using language in communicating properly and correctly.

A learning activity can be said to be successful if it meets the criteria (a) the absorptive capacity of teaching materials to achieve high achievement, both individually and in groups, and (b) the behavior outlined in the specific teaching / instructional objectives (ICT) has been achieved by the students, either individually or in groups (Djamarah and Zain (2006: 105-106). Therefore, in order for learning to succeed, the selection of strategies or approaches in learning must be appropriate and well planned in accordance with the four basic strategies of learning, (b) choosing a learning approach system, (c) selecting and establishing procedures, methods, and instructional techniques; and (d) establishing norms and minimum limits on completeness (Iskandarwassid and Sunendar, 2009: 6 ).

Language learning trains students to pay attention to the values in communication so they can use the language appropriately. Littlewood (1984) states that language learning is a natural response to communication needs (both productive and receptive). Therefore, we must try to convince learners to always pay attention to the communication values of what they learn. Littlewood also stated that in the classroom, anxiety can be a barrier to learning and makes students lazy to express themselves in second language learning. Therefore we must avoid overcriticism of their appearance, try to give the students an opportunity to express themselves, and create a relaxed classroom atmosphere.

Harmer (1983) suggests that components in a balanced activity approach are teachers' ability to adapt and be flexible. Adaptability refers to the ability of teachers to choose and adapt their courses in teaching. While flexibility refers to the behavior of teachers in the classroom and its ability to be sensitive to changes needed to improve learning outcomes. Flexibility means the ability to use a variety of techniques and not just stick to one methodology. 
ISLLAC

Journal of Intensive Studies on Language, Literature, Art, and Culture

Vol. 1 No. 1 September 2017

From the above explanation, it can be concluded that language learning aims to give the ability to learners to communicate in the language he studied. To realize an effective teaching-learning process, there must be cooperation between teachers and learners. Teachers should be able to adapt classroom conditions and be flexible in using appropriate techniques. According to Popham and Baker (Hadi, et al., 1992), effective learning is a learning process that produces a change in students' abilities and perceptions as expected. Furthermore, Popham and Baker explained that an effective teaching and learning process depends on the selection and use of learning methods that are appropriate to the purpose of the teaching and learning process. Meanwhile, Alatis and Altman (1981: 44) propose that in order to maximize effectiveness, a teacher needs to understand the discrepancy between what the student carries in formal language learning situations and the demands requested by the teacher and the text, the demands of the exam system, and the expectations for the prospect forward. In contrast to that opinion, McWhorter (1992: 3) states that efficiency is the ability to show something with less effort, cost, and expenditure. Efficiency involves the effective use of time and resources to accomplish a specific task.

Starting from the above explanation, it can be concluded that effective learning should be done based on the results of student needs analysis. Student needs in question are the relationship between the ability and expectations of students of the learning process. In addition, effective learning should have an overview of the examination system used. So, there must be a match between the needs of the students and the exam system will be done.

\section{LEARNING MATERIAL OF PORTUGUESE LANGUAGE}

Portuguese teaching material is a Portuguese language subject matter that is arranged in a coherent and systematic. Teaching materials provide opportunities for students who are learning to develop their competencies systematically and programmatically. Thus, the students are able to master all competencies in a complete and integrated manner. Sungkono (2003: 1) states that teaching materials 
ISLLAC

Journal of Intensive Studies on Language, Literature, Art, and Culture

Vol. 1 No. 1 September 2017

are a set of materials that contain subject matter designed to achieve learning objectives. On the basis of these needs, it can be argued that the Portuguese teaching materials are "design" Portuguese language subject material embodied in the form of exposure language materials that can be used to study students in and during the learning process.

Teaching materials can contribute greatly to the achievement of student achievement. The importance of the teaching materials function was put forward by the World Bank Report of 1989, which stated that the level of ownership of books and other facilities by learners is positively correlated with the learning achievement it achieves. Results of studies conducted by Heyneman. (1981) indicates that there is a significant correlation between the presence or absence of teaching materials with the learning achievement of learners. The results of this study are confirmed by Patrick (1988), which states that teaching materials are an instructional medium that has a dominant role in the class. Teaching materials also occupy a central role at all levels of education because teaching materials are tools for delivering curriculum materials. Cunningswort (1995), also corroborates the explanation by saying that there is no greater effect on the content and implementation of learning activities other than the teaching materials used.

In the learning process, teaching materials have usefulness for students and teachers who teach them. The role and existence of teaching materials become increasingly important when associated with Portuguese teaching materials as learning materials for students in Timor Leste High School. In Part 1 of the Constitution of the Democratic Republic of Timor Leste, section 13 on Official Languages and National Languages states that Tetum and Portuguese are the official languages of the Democratic Republic of Timor Leste (RDTL). Both languages are nurtured and developed by the State. In addition to these two national languages developed, in Timor Leste there is also English, Indonesian, and a number of regional languages

To improve the role of the Portuguese language in building the nation's character, learning the Portuguese language needs to be improved in quality. 
ISLLAC

Journal of Intensive Studies on Language, Literature, Art, and Culture

Vol. 1 No. 1 September 2017

Improving the quality of learning can be done through the preparation of teaching materials that are truly functional. Topics and content of instructional materials should be able to support the communication needs of students in the community. Thus, the teaching materials have benefits and use for students so that students are interested and motivated to learn Portuguese. In this case, language learning trains students to pay attention to the values in the communication so that they can use the language appropriately.

The above statement is in line with Littlewood's (1984) view that language learning is a natural response to communication needs (both productive and receptive). Therefore, teaching materials need to be cultivated can make learners pay attention to the communication values of what they learn. Littlewood also stated that in the classroom, anxiety can be a barrier to learning and makes students lazy to express themselves in second language learning. Therefore, through the use of learning materials in accordance with the needs of students provide an opportunity for students to express themselves, and create a more interesting classroom atmosphere.

Learning materials that meet the needs of students will make learning more interesting. Thus, the learning process will run more effectively. According to Popham and Baker (Hadi, et al., 1992), effective learning is a learning process that produces a change in students' abilities and perceptions as expected. Furthermore, Popham and Baker explained that an effective teaching and learning process depends on the selection and use of learning methods that are appropriate to the purpose of the teaching and learning process. Meanwhile, Alatis and Altman (1981: 44) propose that in order to maximize effectiveness, a teacher needs to understand the discrepancy between what the student carries in formal language learning situations and the demands requested by the teacher and the text, the demands of the exam system, and the expectations for the prospect forward.

To facilitate the understanding of language materials taught, Portuguese teaching materials need to be packaged in theme units. Each unit begins with dialogue, dialogue enrichment, dialogue exercise, spontaneous dialogue exercises, 
ISLLAC

Journal of Intensive Studies on Language, Literature, Art, and Culture

Vol. 1 No. 1 September 2017

reading comprehension, and practice of reading content. The packaging material is developed communicatively so as to provide opportunities for students to communication practice. This is consistent with the opinion of Littlewood (194: 24) which states that in language learning, the communicative approach emphasizes the purpose of using language according to the context of the conversation. Language learning is directed at efforts to achieve learning objectives, namely the improvement of communicative skills. In this case, the communicative approach directs the language learner to be able to use the language in the actual communication setting. This ability by Savignon $(1984,57)$ is called communicative ability.

In an effort to maximize the practice of language use, the organization of the content of the teaching materials needs to be developed using a communicative approach. The presentation of materials in teaching materials is oriented to the learning process and teaching the language based on the task and function of communicating. This is in accordance with the basic principle of the communicative approach proposed by Siahaan (in Pateda 1991: 86), in (a) the material must consist of language as a means of communication, (b) the design of the material should emphasize the teaching and learning process and not the subject, and (c) materials should encourage learners to communicate fairly.

Each unit in this developed material is presented in the form of examples of dialogue, dialogue, dialogue exercises, and dialogue spontaneously. It is intended to help students achieve the expected competencies. Broadly speaking, teaching materials or learning materials containing knowledge, skills, and attitudes or values that students must learn. Viewed from the teacher, the learning materials should be taught or delivered in the learning activities. Viewed from the students of the teaching materials should be studied by the students in order to achieve the competence to be assessed by using assessment instruments that are prepared based on the indicators of learning achievement.

The development of teaching materials answers the needs of the field related to the difficulty of finding teaching materials that can meet the communication needs of students. These teaching materials have strategic value in learning activities. 
ISLLAC

Journal of Intensive Studies on Language, Literature, Art, and Culture

Vol. 1 No. 1 September 2017

Banathy (in Gatot, 2008) explains that the development of teaching materials is a systematic process of identifying, developing, and evaluating the content and instructional strategies directed toward achieving learning goals more effectively and more efficiently. Syahid (2003) explains that the development of teaching materials is a form of learning strategy development based not on the basis of the interests of developers, but an alternative problem-solving learning.

The development of this resource is based on the needs of the field, especially for Portuguese language learning in Timor Leste. This is in accordance with the opinion of Gatot (2008) states that the objectives of teaching materials development are (1) preparing the learning activities in various situations so that they can take place optimally, (2) increasing the motivation of teachers to manage teaching and learning activities, and (3) teaching by filling in materials that are always new, displayed in a new way and implemented with new learning strategies as well. In line with that opinion, Mbulu (2004: 6) stated that there are four objectives, namely (1) the acquisition of instructional materials in accordance with institutional objectives, curricular goals, and learning objectives, (2) the formation of teaching materials according to the subject content structure with their characteristics (3) synthesizing and sequencing the subject topics systematically and logically, and (4) opening of continuous resource development opportunities referring to the development of science and technology. Furthermore, Kemendiknas (2007) formulates three objectives, namely (1) clarify and facilitate the presentation of messages so as not to be very verbal, (2) overcome the limitations of time, space, and sensory power, both learners and teachers, and (3) can use appropriately and varied.

\section{CONCLUSION}

Based on the above explanation, it can be argued that Portuguese language learning has an important role in building the character of the nation in Timor Leste. Through learning Portuguese, the people of Timor Leste will understand and appreciate the direction of the development of the culture of the nation so that it will be embedded with a sense of nationalism. However, in reality, Portuguese language 
ISLLAC

Journal of Intensive Studies on Language, Literature, Art, and Culture

Vol. 1 No. 1 September 2017

learning in Timor Leste is still experiencing many obstacles. These constraints need to be addressed so that learning can run well and achieve the expected target.

Efforts to overcome the barriers of learning the Portuguese language can be done through the preparation of quality Portuguese learning materials. The components of the developed material need to be adapted to theoretical or field needs. The teaching materials need to be packaged in a book that is interesting and easy to learn by students. Thus, these teaching materials can be used to facilitate and improve the effectiveness and effectiveness of the Portuguese teaching and learning process.

\section{REFERNCES}

Alatis, J. E., Alatis, P., \& Altman, H. (1981). The second language classroom: Directions for the 80s. New York: Oxford University Press.

Banathy, B. (1968). Instructional Systems. Palo Alto, California: Fearon Publishers.

Cunningsworth, A. (1985). Choosing Your Coursebook, Oxford: Heineman.

Degeng, I N. S.. (1997). Strategi Pembelajaran. Malang: IKIP Malang \& LPPPI.

Dimyati \& Mudjiono. (2009).Belajar dan Pembelajaran. Jakarta: Rineka Cipta.

Djamarah, S.B \& Aswan, Z. (2006). Strategi Belajar Mengajar. Jakarta: Rineka Cipta.

Harmer, J. (1983). The practice of English Language Teaching. Longman Handbooks for Language Teachers.

Heyneman, et al. (1981). Textbooks and Achievement in Developing Countries: What We Know, in Journal of Curriculum Studies Vol. 13, No. 3 (1981) 227-246.

Iskandarwassid \& Sunendar, D. (2009). Strategi Pembelajaran Bahasa. Bandung: Remaja Rosdakarya.

Kemdiknas. (2008). Sosialisasi KTSP: Pengembangan Bahan Ajar. Jakarta: Kemdiknas.

Littlewood, W. (1984). Communication Language Teaching. An Introduction. London: Cambridge University Press.

Mbulu, J. \& Suhartono. (2004). Pengembangan Bahan Ajar. Malang: Elang Mas. 
ISLLAC

Journal of Intensive Studies on Language, Literature, Art, and Culture

Vol. 1 No. 1 September 2017

McWhorter, J. (1992). "Pidgins and creoles: An introduction. Edited by Jacques Arends, Pieter Muysken, and Norval Smith". Dalam Lournal of Pidgin and Creole Languages 11:1, 145-151.

Pateda, M. (1991). Linguistik Terapan. Ende-Flores: Nusa Indah.

Patrick, J.J. 1988. Highschool Governement Textbook, dalam ERIC DIGEST ED301532, Desember 1988.

Savignon, S.J. (1986). Communicative Competence: Theory and Classroom Practice. Cambridge: Massachusetts: Addison - Wesley.

Slameto. (2010). Belajar dan Faktor-faktor yang Mempengarubinya. Jakarta: Rineka Cipta.

Sudjana, N. 1996. Penilaian Hasil Proses Belajar Mengajar. Bandung: Rosdakarya.

Sugiyono. (2007). Metode Penilaian Pendidikan Pendekatan Kuantitatif, Kualitatif dan $\mathrm{R} / D)$. Bandung: Alfabeta.

Sungkono. (2003). Pengembangan Bahan Ajar . Yogyakarta: FIP UNY

World Bank. (1989). Indonesia: Basic Education Study. Washington DC: World Bank. 